\title{
Chapter 6. The Lapita Culture and Austronesian Prehistory in Oceania
}

\section{Matthew Spriggs}

The Lapita culture (1600 BC to $500 \mathrm{BC} / \mathrm{AD}$ 1) represents the archaeological record of the first substantial Austronesian colonization into Melanesia and Polynesia. The situation prior to Lapita in western Melanesia (near Oceania) is discussed, together with the archaeology of the Lapita culture itself and questions of correlations with early Oceanic languages and colonizing people. Some observations relevant for an understanding of Austronesian migration are also presented.

\section{Introduction}

The most widespread cultural horizon in Oceania is the Lapita culture, defined initially on the basis of its highly distinctive decorated pottery (see Green 1990 for a "potted" history of Lapita studies). Its geographic spread is from Manus (Admiralties) and the Vitiaz Straits (between New Guinea and New Britain) in the west to Tonga and Samoa in the east (Map 1). On New Guinea itself sherds from a single pot only have been found at Aitape on the north coast of West Sepik Province (Papua New Guinea). The Lapita culture dates from about 1600 $\mathrm{BC}$ to between $500 \mathrm{BC}$ and the time of Christ in different areas, by which time it had lost its more general but distinctive features (see Spriggs 1990a for a discussion of Lapita distribution and chronology).

When the widespread distribution of Lapita was first recognized in the late 1960s and 1970s, it was linked with the spread of Austronesian (An) languages in the region and on occasion interpreted as representing the migration of speakers of these languages from Island Southeast Asia, through Melanesia and out into the Pacific (Bellwood 1978:255; Pawley and Green 1973; Shutler and Marck 1975). In the 1980s, perhaps inevitably, reaction set in against this simple equation, at least as far as Island Melanesia was concerned. The equation for Fiji and Western Polynesia remains generally uncontroversial. The ANU Lapita Homeland Project was formulated in 1983-84 specifically to examine the possibility of local development of the Lapita culture in the Bismarck Archipelago to the immediate east of New Guinea from indigenous roots (Allen 1984). Perhaps equally inevitably the mass of information on the prehistory of Island Melanesia gained from this project and a number of related projects which followed it have complicated the issues rather than resolved them (Allen and Gosden 1991; Gosden et al. 1989). Two very different views have been championed in recent years. Some researchers espouse an almost entirely indigenous development of Lapita in the Bismarcks (Allen and White 1989; White, Allen and Specht 1988) while 
The Austronesians: Historical and Comparative Perspectives

others view it as largely but not exclusively an intrusive culture with its major links further west to Island Southeast Asia (Bellwood, this volume; Green 1991a; Kirch 1988a; Spriggs 1991b, in press). As always there is a tribe of more cautious, or perhaps simply more pusillanimous, fence sitters waiting to see who prevails. 


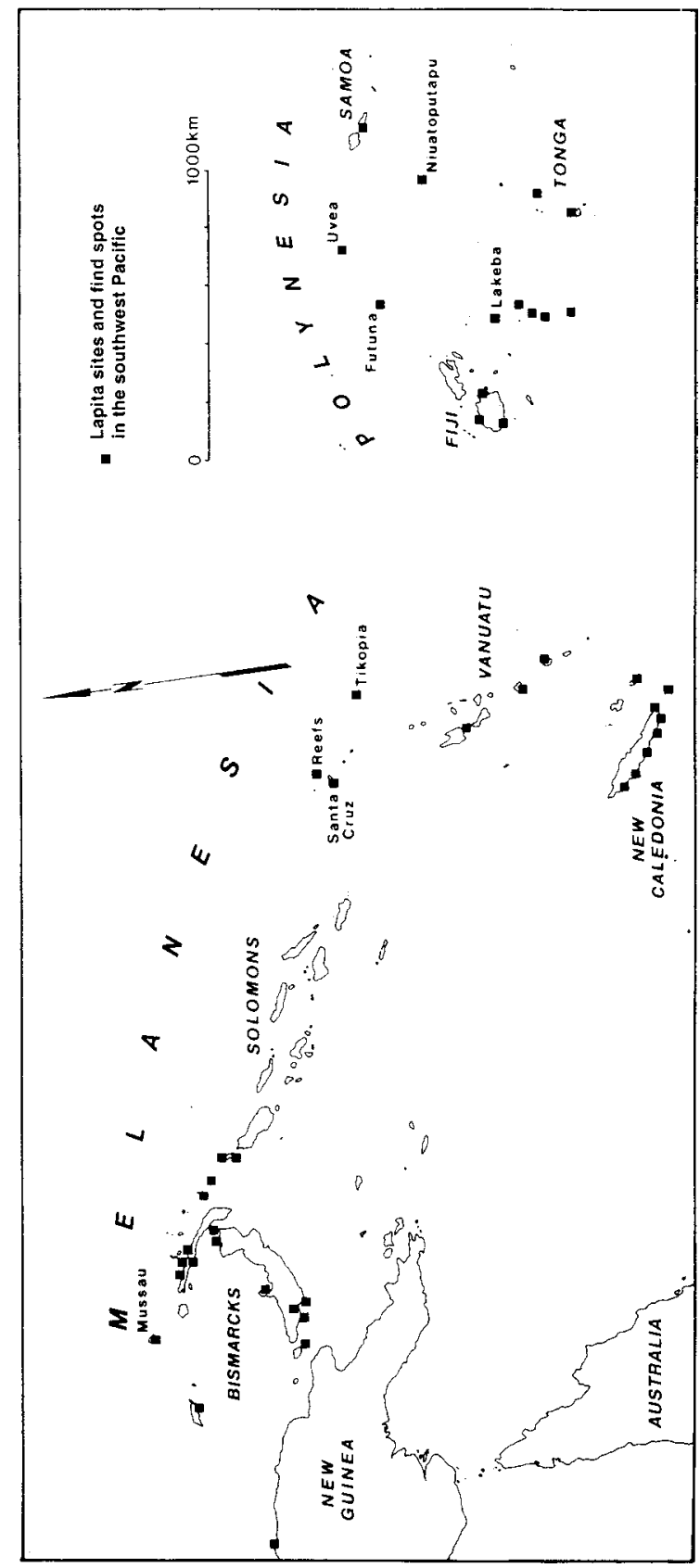

Map 1: Lapita sites and find spots in the southwest Pacific.

The "indigenists" see any argument from language or genetics as being irrelevant to any consideration of the origins of an archaeologically defined entity, an archaeological culture for instance. At one level they are of course right. Much confusion has occurred in the Pacific by the mixing at too early a 
stage of investigation of concepts and terms between disciplines involved in researching the prehistory of the region. Methodologically the best way to proceed in constructing Pacific prehistory is to keep apart the different data bases of archaeology, linguistics and genetics, and keep apart their arguments for constructing prehistories, as long as possible or at least until the excitement becomes too much.

This is what I will attempt to do for Melanesia and Western Polynesia, constructing in outline an archaeological prehistory, before comparing it with the linguistic prehistory presented elsewhere in this volume by Pawley and Ross and by Dutton (see also Ross 1988, 1989), and the genetic prehistory summarized by Bhatia, Easteal and Kirk and by Serjeantson and Gao (see also Hill and Serjeantson 1989). It is in this final necessary step of comparing the different prehistories that the indigenist viewpoint fails because it refuses to engage in any such comparison. There are clearly implications for prehistory in the distribution of language groups and of genetic markers in the Pacific. Failing to address them is throwing out the baby with the bathwater (cf. Anthony 1990).

\section{An Outline of Archaeological Prehistory}

Settlement of the Australia-New Guinea area, then joined as the continent of Sahul, occurred at least 40,000 years ago (White and O'Connell 1982), and there is now thermoluminescence dating evidence for human occupation on the order of 55,000 years ago from northern Australia (Roberts, Jones and Smith 1990). In 1980 the first evidence was obtained for Pleistocene (before 10,000 years ago) occupation of the islands to the east of New Guinea, within the region in Melanesia known as Near Oceania. A date was obtained from a site on New Britain of about 11,400 years ago (Specht, Lilley and Normu 1981). In 1986 dates around 33,000 years old were obtained from New Ireland (Allen et al. 1988; Allen, Gosden and White 1989), and in 1988 came evidence from Buka at the northern end of the Solomons chain for occupation by 29,000 years ago (Wickler and Spriggs 1988). Finally, in 1990 Pleistocene occupation was confirmed for Manus in the Admiralty Islands by research conducted by Wal Ambrose, Spriggs and Clayton Fredericksen.

Initial occupation of New Guinea and the rest of Near Oceania (the Bismarck and Solomon archipelagoes) was by hunting and gathering populations, but possibly by 7000 BC and more certainly by about 4000 BC an indigenous development of agriculture occurred in the New Guinea Highlands, and almost certainly in the lowlands of the island as well. The evidence is from ditching of swamps in the Highlands, significant forest clearance revealed in pollen records (Golson 1977, 1989) and plant macrofossils of several important New Guinea domesticated nut and tree species at the Dongan site in the Sepik-Ramu Basin at 4700 BC (Swadling, Araho and Ivuyo 1991). Equivalent evidence has not been found in the Bismarcks and Solomons, apart from the exploitation of Canarium 
nut trees apparently introduced from the mainland of New Guinea (Yen 1985:320, 1990:262, 268) before the end of the Pleistocene. It is thus possible that an agricultural focus existed in New Guinea, with the adjacent islands pursuing more of a hunting and gathering economy in the immediately pre-Lapita period. This contentious issue is discussed in more detail elsewhere (Spriggs 1993).

Until recently the evidence for an indigenous development of agriculture in New Guinea seemed to sit, at least to me, rather uneasily with introduced pig remains in the New Guinea Highlands at $4000 \mathrm{BC}$ and more uncertainly at 8000 BC. The pig is not indigenous to Melanesia and would have had to have been brought in from Island Southeast Asia (see Groves, this volume). Recent direct dating by accelerator mass spectrometry of pig remains claimed to be from early contexts now raises the possibility that pigs have only been in the Highlands for a much shorter period (David Harris, pers.comm.), although new claims of pig in a $4000 \mathrm{BC}$ context have recently been made for the north coast of New Guinea (Gorecki, Mabin and Campbell 1991:120).

South and east of the main Solomons chain, however, in the area known as Remote Oceania (see Bellwood Map 1, this volume), there is no clear evidence of human settlement earlier than the Lapita culture, dating in Vanuatu and New Caledonia to about 1200 BC. For this part of Melanesia and for Western Polynesia, Lapita appears to be the founding culture (see Green 1991b and Spriggs 1989b for discussion).

As mentioned at the beginning of this paper, Lapita was initially defined on the basis of its highly distinctive pottery, decorated by dentate (toothedstamp) impression. With the possible exception of the Sepik-Ramu pottery (Swadling, Araho and Ivuyo 1991), it is the earliest pottery tradition in Melanesia. Lapita-like decoration is not found in earlier pottery assemblages in Island Southeast Asia (it does occur there slightly later — Spriggs 1989a:607), but the range of vessel forms and the use of red-slip decoration are shared between the two regions.

There are now three sub-styles of Lapita recognized (Anson 1983, 1986), which have geographical and chronological significance (Spriggs 1990b).

1. Far Western, or as I would prefer "Early Western", Lapita is limited to the Bismarck Archipelago and dates from about 1600 to 1200 BC or slightly later. This sub-style has produced the most complex vessel forms and the most elaborate decorative motifs, often executed using extremely fine dentate stamps.

2. Western Lapita is found after $1200 \mathrm{BC}$ in the Bismarcks and represents the earliest Lapita pottery in the Solomons, Vanuatu and New Caledonia. It consists of less elaborate decoration, fewer vessel forms and generally the use of coarser stamps. This sub-style lasts until about the time of Christ in 
some areas while in others dentate-stamping as a decorative technique had ceased by 500 BC. An example is given in Figure 1.

3. Eastern Lapita is found in Fiji and Western Polynesia starting around 1000 BC. The motifs are simpler still and there are fewer vessel forms. A coarse dentate-stamping is often used. In Tonga the sub-style may have continued in use until about 2000 years ago, whereas in Samoa it appears to have ceased much earlier by about $800 \mathrm{BC}$. This sub-style is related most closely to the Western style Lapita assemblage of Malo in northern Vanuatu.

The tendency in Lapita pottery is for simplification through time, and as the style spread from west to east. In all areas of its distribution vessel forms and decoration became less elaborate over time. Finally the vessels either become entirely plain or are decorated with incised and/or applied relief designs. These latter decorative techniques are present but rare in earlier Lapita assemblages.

But Lapita is not just pots. There is a whole "package" of material culture items and other distinctive features which like the pottery are not found in earlier cultural assemblages. The existence of this distinctive assemblage is often underplayed by those who argue that Lapita developed in Melanesia with minimal external input. Evidence that Lapita does represent some kind of break with preceding assemblages in Melanesia is evident from the following observations:

1. South and east of the main Solomons Lapita is the founding culture, representing the first human occupation of Remote Oceania.

2. Everywhere Lapita is found it marks the first appearance in Island Melanesia of the three Oceanic domesticates - the pig, dog and chicken, all derived from Island Southeast Asia, as well as the commensal Polynesian rat (Rattus exulans), again of Asian origin. 

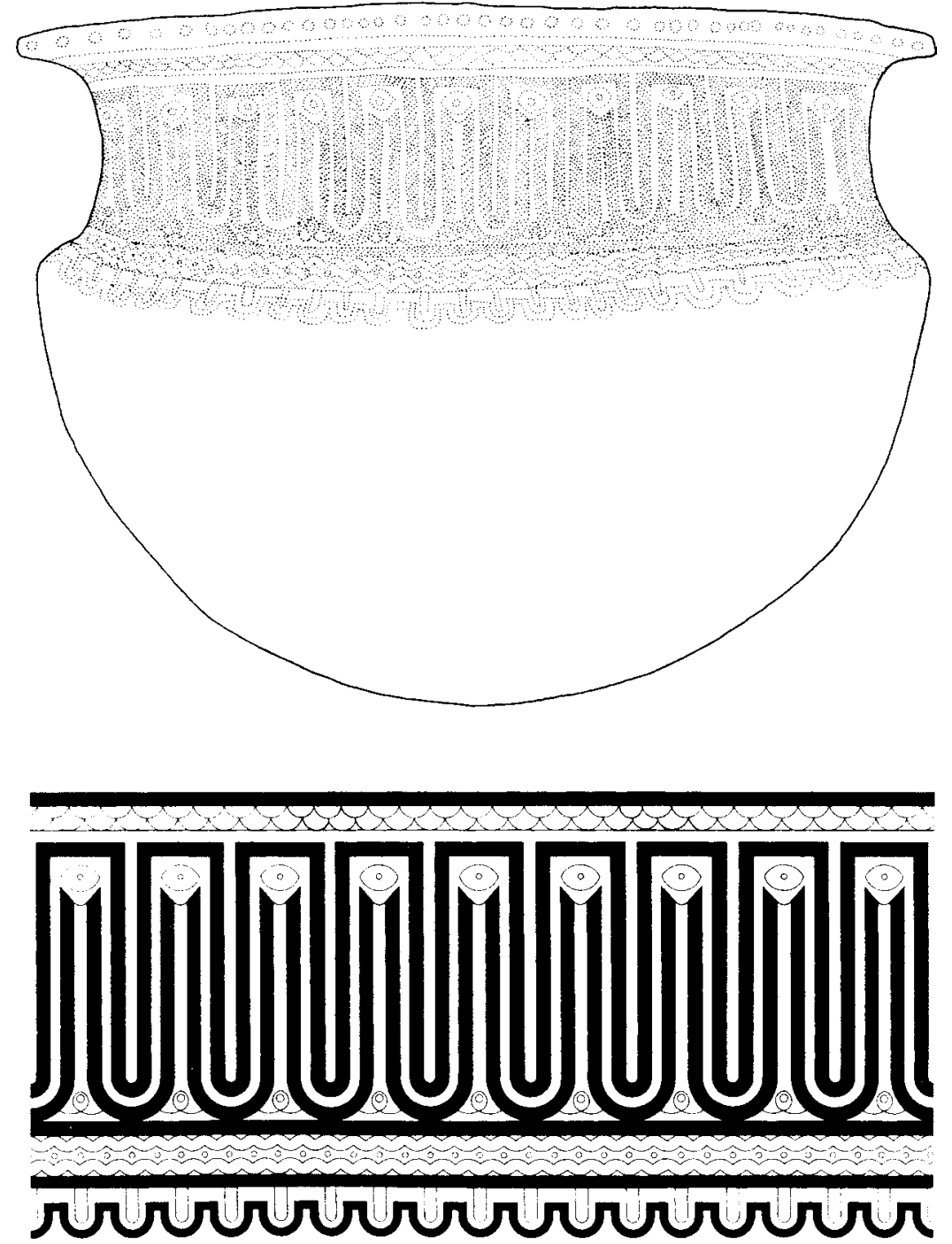

Figure 1: A dentate-stamped pottery vessel from Malo Island, Vanuatu. The bottom figure is a simplified version of the dentate-stamped composition shown above.

3. There is a distinctive Lapita stone adze kit, in part an innovation of the Lapita culture and in part derived from Island Southeast Asian adze forms (Green 1991a).

4. There are distinctive Lapita shell ornament types (Kirch 1988b), some of which also occur in Neolithic Island Southeast Asian assemblages.

5. A major extension in the range of distribution of Talasea (New Britain) and Lou Island (Admiralties) obsidian occurs with Lapita. Lou Island obsidian 
is not found outside the Admiralties Group in pre-Lapita times. But it is found in Lapita sites throughout the Bismarcks, Solomons and into Vanuatu. Talasea obsidian was distributed pre-Lapita to the west on the New Guinea mainland as far as the Sepik-Ramu Basin, ${ }^{1}$ and to the south and east in New Ireland and on Nissan, an island between New Ireland and the Northern Solomons (Spriggs 1991a). In Lapita times its distribution encompassed Sabah in Borneo (Bellwood and Koon 1989) to the west and Fiji in the east (Best 1987), a spread of some $6500 \mathrm{~km}$.

6. Lapita possesses a distinctive settlement pattern of large villages, often consisting of stilt houses over lagoons or on small offshore islands, and certainly always within a kilometre or two of the shore. Lapita sites do not generally re-occupy previously used locations except in rockshelters. The settlement pattern suggests a defensive posture or avoidance of mainland situations where malaria might have been rife.

7. There is evidence in the vicinity of Lapita sites for extensive forest clearance and higher than previous erosion rates, suggestive of an agricultural basis to the economy (Gosden et al. 1989:573).

8. Lapita also represents the movement out into the Pacific of a wide range of domesticated plants, of either Southeast Asian or New Guinea origin. Macrofossils of these plants are found in many Lapita sites, but in Island Melanesia have not so far been found in earlier archaeological contexts (Gosden et al. 1989:573-574).

The question of the origin of the Lapita crop complex remains unresolved. Island Southeast Asian Neolithic cultures were at least initially rice-using and yet rice was not transferred across to Melanesia. Yen $(1982,1985,1990)$ has challenged the earlier assumption that the crop complex carried into the Pacific by the Lapita culture was also of Asian or Southeast Asian origin. The wild progenitors of many of these crops can now be seen as of New Guinea origin, in line with the evidence mentioned previously for an early centre of plant domestication in this area.

Three questions are raised by this. How far in the islands to the west of mainland New Guinea did the process of pre-Lapita domestication extend? Secondly, how much further had the domesticates themselves spread in pre-Lapita times? Thirdly, could some of the plants in question have been domesticated independently in areas of Southeast Asia and in New Guinea? As the area immediately west of New Guinea, and indeed the western half of New Guinea itself, are still little explored archaeologically, no answers to these questions can yet be formulated. To the extent that the Lapita crop complex may have been picked up from the New Guinea region rather than Island Southeast Asia, there is a wide area in which any crop transfer could have occurred - from eastern Indonesia and along the north coast of New Guinea to the Bismarcks. The lack 
of evidence so far for many of these plants in pre-Lapita contexts in the Bismarcks gives no reason to suggest primacy for that area in any such transfer. It may have occurred earlier and far to the west.

What does Lapita culture represent in the various areas where it occurs? In Remote Oceania including Polynesia it represents initial colonization by human groups, equipped with a fully agricultural economy. In Near Oceania (the Bismarcks and Solomons) it represents the first appearance of domestic animals, a range of new artefact forms including pottery, a shift in settlement patterns, dramatic changes in obsidian exchange networks and the first clear evidence for an agricultural base to the economy.

Because of a dearth of immediately pre-Lapita sites, it is hard to assess continuities in Lapita from pre-Lapita cultures in Near Oceania. Where these do occur some continuities are apparent. Canarium nut exploitation remains an important part of the economy. There is continuity too in some artefact types: Tridacna (clam) shell adzes, Trochus shell armrings, simple shell beads and probably simple one-piece shell fishhooks (Spriggs 1991b). The discontinuities, however, seem more substantial, given the many new artefact types in the Lapita inventory listed previously. In the Talasea area of New Britain comparison is hampered by preservation conditions such that organic materials (including shell) are not preserved. Pre-Lapita and Lapita period obsidian technologies there, however, are extremely different with an earlier elaborate blade industry not continuing into Lapita levels (Torrence, Specht and Fullagar 1990). Apart from the Talasea area, there are few obviously pre-Lapita open sites and many of the previously inhabited rockshelters went out of use between about 6000/4000 $\mathrm{BC}$ and the Lapita or immediately post-Lapita period.

On the island of New Guinea itself, Lapita does not represent anything apart from the fragments of a single pot, seemingly of a late Lapita style. There is a comparable but somewhat later phenomenon, however, in the archaeologically instantaneous spread of the Papuan red-slipped pottery style found west to east along the south coast of Papua at about AD 200 (Irwin 1980, 1991). The spread is again associated with a distinctive settlement pattern, long-distance movement of obsidian (this time from Fergusson Island sources in Milne Bay Province, PNG) and other items of material culture ultimately derivable from the Lapita culture of the Bismarcks. This pottery tradition is the earliest along the south coast of the island of New Guinea. Slightly later again after AD 500 pottery appears along the north coast and on islands offshore from Madang Province, related again to the Bismarcks assemblages (Lilley 1988). As already mentioned the status and age of the Sepik-Ramu pottery styles are not yet clear, but they are certainly not in the Lapita style.

I would argue that the dates for pottery in Island Melanesia in relation to Southeast Asia, the rapid spread of Lapita culture, the nature of the new material 
culture items, the Southeast Asian links for the domestic animals and the pottery vessel forms and red slip, and the distinctive settlement pattern argue for Lapita culture representing a migration into the Bismarcks from areas to the west in Island Southeast Asia. Lapita culture, though intrusive, did not exist isolated from the already existing cultures of the area and there is some carry-over in material culture items and continuing exploitation of the major obsidian sources. There appears to have been a pause of some 400 or so years in the Bismarcks, ample time for significant interaction with local populations, before the culture spread through the Solomons and out into Remote Oceania at about 1200-1000 BC.

When the Lapita design system disappears in Island Melanesia and Fiji between about $500 \mathrm{BC}$ and $\mathrm{AD} 1$, different pottery styles derivable from the non-dentate-stamped "domestic ware" of Lapita appear from Manus to Fiji. Vanuatu obsidian and pottery types appear in Fiji at this time (Best 1984, 1987), evidence of renewed contacts to the west. The changes in pottery style might represent further population movements or alternatively continuity of groups who remained in interaction over the previous range of Lapita in Melanesia as I have argued previously (Spriggs 1984; see also below).

The archaeology of Micronesia is much less understood (see Craib 1983 for summary). The Mariana Islands appear to have been first settled at about 1200-1000 BC (Bonhomme and Craib 1987) and there are some very specific parallels with Island Southeast Asian pottery of the same general period. The rest of Micronesia has so far only produced sequences for the last 2000 years. Plain and rim-notched pottery from Eastern Micronesia could plausibly be derived from late Lapita assemblages (Athens 1980).

\section{Comparison with Linguistic Prehistory: A Lapita Language?}

The details of current thinking on linguistic prehistory in Oceania are presented elsewhere in this volume, where detailed references should be sought. If we compare the two prehistories there is indeed a striking fit, although diversity in interpretations among linguists should be acknowledged. Ross $(1988,1989)$ situates the Proto-Oceanic homeland in the general area of the Willaumez Peninsula (Talasea area), on the north coast of New Britain (cf. Grace 1961:364), which was as we have seen an important centre for the distribution of obsidian in Lapita times. The distribution of the Oceanic An languages and the distribution of Lapita and its successor cultures are also coincident. Ross sees an early movement of An languages to Manus, the other centre for obsidian distribution in the Lapita period, and another movement out through the Solomons into Vanuatu and New Caledonia, and ultimately to Fiji and Polynesia. This spread of a branch of Oceanic into and beyond the Solomons is matched by the distribution of the Western and Eastern Lapita sub-styles. The Central Pacific languages (Fijian, Rotuman and Polynesian) have their closest relatives in 
northern Vanuatu and the Eastern Lapita sub-style, which covers the same area, has its closest relation to the pottery from Malo in northern Vanuatu (Anson 1983, 1986).

In Polynesia the break-up of Proto-Polynesian into the Tongic and Nuclear Polynesian linguistic groups matches exactly the division between Tonga and Samoa in material culture during the Lapita period. Almost immediately after initial settlement at about 1000 BC dentate-stamped pottery was replaced by plainware in Samoa, while in Tonga use of some dentate stamping continued until almost the time of Christ (Kirch, Hunt and Tyler 1989; Poulsen 1987). When evidence for settlement further out into the Pacific occurs at about $200 \mathrm{BC}$ or later in the Marquesas it is associated with plainware generally similar to that from Western Polynesia and Fiji (Kirch 1986). All Eastern Polynesian languages are derived from the Nuclear rather than the Tongic branch of Polynesian (see Clark 1979 for a succinct discussion of Polynesian languages).

The clear correlation of the distribution of Lapita with the distribution of Oceanic An languages suggests that Proto-Oceanic split up by about 1200 BC with the movement of Lapita culture beyond the Bismarcks. Linguistic change after that may have been extremely rapid. Proto-Central Pacific must have developed its few distinctive features around 1000 BC and Proto-Polynesian could have developed soon afterwards, possibly already starting to diverge into what became the Tongic and Nuclear Polynesian groups soon after 800 BC.

The languages of the Marianas and Belau (formerly Palau) and possibly Yap in Western Micronesia are An but not Oceanic, being of Western Malayo-Polynesian type (see Tryon, this volume). The other Micronesian languages are assigned to a subgroup of Oceanic termed Nuclear Micronesian. Although various subgrouping arguments have been put forward to link Nuclear Micronesian with other subgroups within Oceanic, there is no general agreement as to their immediate external relationships (Jackson 1986). Archaeology does not yet suggest a more specific point of dispersal in Island Melanesia. The generally plain or notched-lip pottery found in Micronesian contexts back to about 2000 years ago can be matched in a wide area of Island Melanesia from Manus to Vanuatu at the same time period.

The situation in the Bismarcks and the north-western Solomons has been complicated according to Ross (1988) by the subsequent spread of the Western Oceanic languages of the Meso-Melanesian cluster from New Britain, which may have in part replaced An languages of probable Southeast Solomonic type in Bougainville and presumably also in New Ireland. It is tempting to link this hypothesized language spread to the replacement of recognizably Lapita pottery by the incised and applied relief styles which are found from the Bismarcks to Fiji. While the linguistic influence is argued by Ross to have stopped at the southern end of Santa Ysabel in the Western Solomons, at the so-called 
Tryon-Hackman line, the suggested archaeological signature of this process continued further south, ultimately to Fiji. If there was a secondary movement of population from the Bismarcks to the south and east, it was a movement from the same general area as the original Lapita spread and so may not have been represented by a distinctive material culture apart from a new pottery style. It should be noted that Ross' idea of a two-stage spread of An languages in the New Ireland-Solomons area has yet to convince other linguists working in the region (Andrew Pawley, pers.comm.).

The two other branches of Western Oceanic An, the Papuan Tip Cluster and the North New Guinea Cluster (Ross 1988), also have close parallels with the distribution of archaeological phenomena. The distribution of the Papuan red-slipped ware and its attendant material culture almost exactly matches the distribution of the Papuan Tip Cluster languages. The pottery making centre of Mailu along the South Papuan coast is now Non-Austronesian (NAn) speaking, but this is obviously a recent switch (Dutton 1982). Genetically the Mailu population is grouped with other South Coast Papuan An-speaking populations (Kirk 1989:100-101). Although much less studied, the spread of pottery use along the North New Guinea coast, and indeed up the Markham Valley as well, corresponds to the distribution of the North New Guinea Cluster An languages. The association between archaeological and linguistic distributions suggests that the movement of Papuan Tip Cluster speakers to the west along the Papuan coast took place rapidly about 1800 years ago and the time depth for the spread out from the Bismarcks area of North New Guinea Cluster languages is almost certainly within the last 2500 years.

One feature of many of the Western Oceanic languages is that they have undergone linguistic change as a result of contact with Non-Austronesian (NAn) languages, initially in the New Britain area, and subsequently as they spread to New Guinea and probably along already-trodden An paths in the Bismarcks and northern Solomons. These languages would have been the first An languages to be spoken in at least the eastern half of the island of New Guinea, which prior to $500 \mathrm{BC}$ was entirely NAn-speaking. Although the associated incised and applied relief pottery styles have their origins in Lapita, they are presumably also heavily informed by the NAn cultural traditions of neighbouring groups. In this sense we can see the intrusive Austronesian Lapita tradition becoming progressively "Melanesianized" by contact-induced change and innovation to produce the range of local cultural styles found in the area in the recent past.

The movement of An speakers to mainland New Guinea in the last 2500 years may have marked the introduction of the pig, so important in the ethnographically recorded cultures particularly of the Highlands. It is noteworthy that the pig is a case where archaeological and linguistic prehistories did not at first appear to match. It has been known for some time that the word for pig is 
an An loan word in many New Guinea NAn languages (Blust 1976). How was this fact to be squared with evidence for pig in New Guinea at 6000 or even 10,000 years ago? The advances in archaeological dating techniques mentioned earlier now suggest that the pig may be late in New Guinea, late enough to have been brought in by An speakers.

\section{A Lapita People? The Evidence from Genetics}

As with the linguistic evidence, genetic studies are treated elsewhere in this volume. For many of the more recently discovered genetic systems, sample coverage is spotty compared to that in archaeology and linguistics. For example, there has not been a great deal of work in the Bismarcks, an area critical for comparison with the archaeological and linguistic pictures. Many of the genetic data were collected for purposes of applied medical rather than historical research and this should also be remembered. That said, the genetic prehistory established so far does seem consonant with the prehistories derived from the other two disciplines.

If we start with Polynesia and work backwards, the pattern is clearer. Initial settlement of Polynesia by the Lapita culture and lack of evidence for any but Polynesian sub-group languages there would suggest Polynesians, a genetically homogeneous group, are direct descendants of the bearers of Lapita culture. An ultimate origin in Island Southeast Asia for the "Pre-Polynesians" now seems certain, with some evidence of genetic admixture with populations in northern Island Melanesia, as summarized by Serjeantson and Hill:

The lack of particular coastal New Guinea [genetic] markers in Polynesians, such as the high-frequency $-\boldsymbol{\alpha}^{4.2}$ thalassaemia deletion, the albumin NG variant, the HLA-B13.Cw4 haplotype, and the B allele of the $\mathrm{ABO}$ blood group, all argue that the pre-Polynesians moved rapidly through this part of Melanesia. However, the presence of a substantial frequency of the Melanesian $\alpha$-globin haplotypes IIIa and IVa in all Polynesians indicates that at some point there was significant interbreeding with Melanesians. The presence of the $-\alpha^{3.7}$ III but not the $-\alpha^{4.2} \alpha$ thalassaemia deletion indicates that this contact was probably mainly in northern island Melanesia rather than in New Guinea (1989:287-288).

Not all bearers of the Lapita culture moved to Polynesia of course. The genes of the "stay at homes" can be found in coastal and island Melanesian groups who are genetically the descendants both of the pre-Lapita populations in the area and of the intrusive Southeast Asian populations who also gave rise to the Polynesians. The latest evidence indicates that Fijians have undergone admixture with Island Melanesians since first settlement by Lapita groups, thus reinstating 
an earlier and partly discredited view of Fijian culture history (Serjeantson and Hill 1989:288-289). The original Fijian population would have been more Polynesian in appearance. This might also have been true of the initial settlers of Vanuatu and New Caledonia. The new genetic evidence is also against any direct link between Polynesians and Micronesians. Micronesian populations are diverse but in general are a distinct Island Southeast Asian population with genetic input from Melanesia in varying degrees (Serjeantson and Hill 1989:290-291). Polynesian populations cannot be derived from Micronesia, as Howells (1973) once believed.

Thus there may have been a moment in the Bismarcks when there was a single people using Lapita pottery, genetically, linguistically and culturally distinct from their neighbours. But this unity and distinctiveness would have been shortlived. Lapita-using populations which spread to Polynesia and those in Island Melanesia subsequently had divergent genetic and linguistic histories. The end of Lapita culture in these two areas also meant very different things. In Island Melanesia rapid transformations in material and other aspects of culture occurred, previous An languages in parts of the Bismarcks and Northern Solomons were replaced by languages of Western Oceanic An-type, and there was perhaps another phase of migration through Island Melanesia of Bismarcks area populations which further swamped the "pre-Polynesian" genotypes. In Polynesia seemingly more gradual changes occurred to produce the cultures of the area recorded in the recent past, their An languages conservative and their art forms still clearly recognizable as Lapita-derived. ${ }^{2}$ Their homogeneous physical type compared to the more differentiated populations of Island Melanesia bears witness to these developments having occurred in comparative isolation.

\section{The Structure of Austronesian Migration in Oceania}

Anthony (1990) has urged that prehistoric migrations be considered as structural processes, the study of which can be approached through general principles derived from recent studies of migration in demography and geography. It may be worth examining some of these postulated principles in the light of the Lapita evidence. ${ }^{3}$ Anthony notes that a common feature of long-distance migration is leapfrogging, great distances being crossed and large areas bypassed, "through the agency of advance 'scouts' who collect information on social conditions and resource potentials and relay it back to the potential migrants" (1990:902). He suggests that archaeologically this should be recognizable by an earlier smallscale penetration prior to the large-scale migration, and notes significantly that the archaeological signature of leapfrogging, "should resemble 'islands' of settlement in desirable or attractive locations, separated by significant expanses of unsettled, less desirable territory" (1990:903).

This of course is precisely the Lapita settlement pattern. "Scouts" too may explain anomalous Lapita assemblages such as the somewhat ephemeral 
rockshelter occupation on Nissan, at the northern end of the Solomons, of the Halika phase, contemporary with the earliest Lapita further to the north and west and stratigraphically below a classic Lapita assemblage at one of the excavated sites (Spriggs 1991a). Lapita rockshelter occupations on Lakeba in Eastern Fiji, interpreted by Best (1984) as representing a "strandlooper" phase of Lapita before the establishment of a fully agricultural economy, would also fit the pattern.

Another feature of long-distance migration discussed by Anthony is its resemblance to a stream, the migrants proceeding along well-defined routes towards specific destinations, and often originating from a highly restricted point of origin. The archaeological signature would be distribution of regionally defined artefact types from a circumscribed home region to a specified destination. The pattern of obsidian distribution in the western Pacific could certainly be interpreted in this framework (cf. Green's (1987:246) discussion of maintaining "ties" with the homeland by continuing to import obsidian from Bismarcks sources when a local alternative was available). Anthony further notes that migration streams often continue to flow in a given direction despite circumstances quite changed from those that prompted the initial movement:

Kinship linkages, dependence, and the reduction of obstacles may attract a secondary flow that is quite different in goal orientation and composition from the initial migrant group. Such a chronological shift in group composition and organization might well have archaeological effects (1990:904).

The changes which occur at the end of Lapita may form an example of such a secondary stream. Migration streams, Anthony notes, favour the creation of "apex-families" which might establish more permanent status differentiation as communities mature. The suggested hierarchical nature of Lapita society (see Kirch 1988 b for discussion) could well have been related to such processes.

A third feature of migration is return migration, a counterstream returning back to the migrants' place of origin, particularly when opportunities are similar at the origin and destination points. Some examples of long-distance "trade" might represent goods carried by return migrants. In this regard it is worth remembering the Talasea obsidian in Sabah and the similarities in pottery decoration to Lapita of assemblages in various parts of island Southeast Asia which date a few hundred years later than the earliest Lapita in Island Melanesia (see above).

A fourth feature is migration frequency, migrants tending to belong to groups who have a tradition of migration. Within particularly the younger age groups of a population, migration increases the probability that further migration will occur. Anthony (1990:905) suggests that this self-propagating tendency can 
partially explain flurries of migratory activity that characterize some portions of the archaeological record. The rapidity of spread of Lapita from the Bismarcks to Samoa in only a few hundred years would seem to be a classic example of this pattern.

Anthony mentions as a final pattern, that of migration demography, often skewed towards males in the initial stages of more recently documented migrations. Some of the "bottlenecks" detected by mitochondrial DNA studies, for instance in the settlement of Eastern Polynesia, might usefully be examined with this in mind. Further modelling of Lapita-period population dynamics along the lines started by McArthur, Saunders and Tweedie (1976) and Black (1978) are clearly needed.

\section{Conclusions}

Peter Bellwood (this volume) has already discussed possible reasons for the expansion of An speakers into the Pacific, although as Anthony (1990:898) points out, the causes of migrations are often extremely complex and in many prehistoric cases proximate causes can no longer be clearly identified. The migrants' initial success in establishing settlements in the Bismarcks and Solomons may well have been due to the demographic muscle imparted by a full-on agricultural economy moving into a basically hunter-gatherer area. The existence of an already in-place agricultural economy on the mainland of New Guinea may well explain why An settlement there appears to have been delayed for over a thousand years after the Bismarcks were settled (Bellwood 1984). It would be wrong, however, to see the new colonists immediately blanketing the Bismarcks and Solomons. Initial numbers would have been low, settlements were marginal to the larger islands and even before the push through to Polynesia some limited recruitment from local NAn-speaking populations must have taken place to explain certain genetic markers found in Polynesian populations.

The diffusion of agriculture across the An-NAn linguistic boundary must have occurred at some time, as all Bismarcks and Solomons populations are agricultural today whatever language they speak. Over time there must also have been a tendency for whole groups to switch from NAn to An languages in areas such as Manus and New Ireland. On Bougainville the majority of the population never adopted An languages, which mimic the mainland New Guinea pattern in occurring peripherally around the coast (Spriggs 1992). The archaeological study of the An and agricultural "frontier" in the region has barely begun but will produce a much more complex prehistory than we can outline with our present state of knowledge.

Although this and other papers in this volume have inevitably given an Austronesian-centred view of the region, all present Austronesian groups, whether in Melanesia or Polynesia, also share a heritage derived from a 
Non-Austronesian Melanesian origin, whether it be in the food crops they cultivate, aspects of their material culture and art, certain genetic markers, or in aspects of the structure and lexicon of their languages. This should not be forgotten because (with apologies to Rupert Brooke) there is a corner of an Austronesian field that is forever Non-Austronesian.

\section{Acknowledgements and Dedication}

I would like to thank Andrew Pawley for particularly trenchant criticisms of an earlier draft of this paper and Nancy Sharp for more restrained comments. It has also been honed by comments on oral presentations of an earlier version by audiences at the Universities of Copenhagen, Lund, Sheffield, Oxford and Cambridge, as well as those at the Austronesians in History Conference at the Australian National University. This paper is dedicated to my wife Ruth Vatoa Saovana of the Wa-Do (Tinputz) language area, part of the Meso-Melanesian Cluster of Western Oceanic Austronesian languages, descendant too of those Bougainville non-Austronesian speakers who got there first.

\section{References}

Allen, J.

1984 In search of the Lapita homeland. Journal of Pacific History 19:186-201.

Allen, J. and C. Gosden (eds)

1991 Report of the Lapita homeland project. Occasional Papers in Prehistory No. 20. Canberra: Department of Prehistory, Research School of Pacific Studies, The Australian National University.

Allen, J., C. Gosden, R. Jones and J.P. White

1988 Pleistocene dates for human occupation of New Ireland, northern Melanesia. Nature 331:707-709.

Allen, J., C. Gosden and J.P. White

1989 Human Pleistocene adaptations in the tropical island Pacific: recent evidence from New Ireland, a greater Australian outlier. Antiquity 63:548561.

Allen, J. and J.P. White

1989 The Lapita homeland: some new data and an interpretation. Journal of the Polynesian Society 98(2):129-146.

Anson, D.

1983 Lapita pottery of the Bismarck Archipelago and its affinities. PhD thesis, University of Sydney. 
1986 Lapita pottery of the Bismarck Archipelago and its affinities. Archaeology in Oceania 21:157-165.

Anthony, D.W.

1990 Migration in archaeology: the baby and the bathwater. American Anthropologist 92:895-914.

Athens, J.S.

1980 Pottery from Nan Madol, Ponape, Eastern Caroline Islands. Journal of the Polynesian Society 89:95-99.

Bellwood, P.S.

1978 Man's conquest of the Pacific. London: Collins.

1984 The great Pacific migration. In Yearbook of science and the future for 1984, pp.80-93. Encyclopaedia Britannica.

Bellwood, P. and P. Koon

1989 'Lapita colonists leave boats unburned!' The question of Lapita links with Island Southeast Asia. Antiquity 63:613-622.

Best, S.

1984 Lakeba: the prehistory of a Fijian Island. PhD thesis, University of Auckland. Ann Arbor: University Microfilms.

1987 Long distance obsidian travel and possible implications for the settlement of Fiji. Archaeology in Oceania 22:31-32.

Black, S.

1978 Polynesian Outliers: a study in the survival of small populations. In I.

Hodder (ed.) Simulation studies in archaeology, pp.63-76. Cambridge:

Cambridge University Press.

Blust, R.A.

1976 Austronesian culture history: some linguistic inferences and their relations to the archaeological record. World Archaeology 8:19-43.

Bonhomme, T. and J. Craib

1987 Radiocarbon dates from Unai Bapot, Saipan: implications for the prehistory of the Mariana Islands. Journal of the Polynesian Society 96:95-106.

Clark, R.

1979 Language. In J.D. Jennings (ed.) The prehistory of Polynesia, pp.249-270. Cambridge, Mass.: Harvard University Press.

Craib, J. 
1983 Micronesian prehistory: an archaeological overview. Science 219:922927.

Dutton, $\mathrm{T}$.

1982 Borrowing in Austronesian and Non-Austronesian languages of coastal South-East Mainland Papua New Guinea. In A. Halim, L. Carrington and S.A. Wurm (eds) Papers from the third international conference on Austronesian linguistics, vol.1: Currents in Oceanic, pp.109-177. Pacific Linguistics Series C No. 74. Canberra: Department of Linguistics, Research School of Pacific Studies, The Australian National University.

Golson, J.

1977 No room at the top: agricultural intensification in the New Guinea Highlands. In J. Allen, J. Golson and R. Jones (eds) Sunda and Sahul: Prehistoric studies in Southeast Asia, Melanesia and Australia, pp.601638. London: Academic Press.

1989 The origins and development of New Guinea agriculture. In D.R. Harris and G.C. Hillman (eds) Foraging and farming: the evolution of plant exploitation, pp.678-687. London: Unwin Hyman.

Gorecki, P., M. Mabin and J. Campbell

1991 Archaeology and geomorphology of the Vanimo coast, Papua New Guinea. Archaeology in Oceania 26(3):119-122.

Gosden, C., J. Allen, W. Ambrose, D. Anson, J. Golson, R. Green, P. Kirch, I. Lilley, J. Specht and M. Spriggs

1989 Lapita sites of the Bismarck Archipelago. Antiquity 63:561-586.

Grace, G.

1961 Austronesian linguistics and culture history. American Anthropologist 53:359-368.

Green, R.C.

1979 Early Lapita art from Polynesia and Island Melanesia: continuities in ceramic, barkcloth and tattoo decorations. In S.M. Mead (ed.) Exploring the visual art of Oceania, pp.13-31. Honolulu: University of Hawaii Press.

1987 Obsidian results from the Lapita sites of the Reef/Santa Cruz Islands. In W. Ambrose and J. Mummery (eds) Archaeometry: further Australasian studies, pp.239-249. Canberra: Department of Prehistory, Research School of Pacific Studies, The Australian National University.

1990 Lapita design analysis. The Mead system and its use: a potted history. In M. Spriggs (ed.) Lapita design, form and composition: Proceedings of the Lapita design workshop, Canberra, December 1988, pp.33-52. Occa- 
sional Papers in Prehistory No. 19. Canberra: Department of Prehistory, Research School of Pacific Studies, The Australian National University.

1991a The Lapita cultural complex: current evidence and proposed models. Bulletin of the Indo-Pacific Prehistory Association 11:295-305.

1991b Near and remote Oceania: disestablishing 'Melanesia' in culture history. In A.K. Pawley (ed.) Man and a half: Essays in Pacific anthropology and ethnobiology in Honour of Ralph Bulmer, pp.491-502. Auckland: The Polynesian Society.

Hill, A.V.S. and S.W. Serjeantson (eds)

1989 The colonization of the Pacific: a genetic trail. Oxford: Clarendon Press.

Howells, W.

1973 The Pacific Islanders. London: Weidenfeld and Nicolson.

Irwin, G.J.

1980 The prehistory of Oceania: colonization and cultural change. In A. Sherratt (ed.) The Cambridge encyclopedia of archaeology, pp.324-332. Cambridge: Cambridge University Press.

1991 Themes in the prehistory of Coastal Papua and the Massim. In A.K. Pawley (ed.) Man and a half: essays in Pacific anthropology and ethnobiology in Honour of Ralph Bulmer, pp.503-510. Auckland: The Polynesian Society.

Jackson, F.H.

1986 On determining the external relationships of the Micronesian languages. In P. Geraghty, L. Carrington and S.A. Wurm (eds) FOCAL II: Papers from the fourth international conference on Austronesian linguistics, pp.201238. Pacific Linguistics Series C No. 94. Canberra: Department of Linguistics, Research School of Pacific Studies, The Australian National University.

Kirch, P.V.

1986 Rethinking East Polynesian prehistory. Journal of the Polynesian Society 95(1):9-40.

1988a The Talepakemalai Lapita site and Oceanic prehistory. National Geographic Research 4:328-342.

1988b Long-distance exchange and island colonization: the Lapita case. Norwegian Archaeological Review 21(2):103-117.

Kirch, P.V., T.L. Hunt and J. Tyler

1989 A radiocarbon sequence from the Toaga Site, Ofu Island, American Samoa. Radiocarbon 31(1):7-13. 
Kirk, R.L.

1989 Population genetic studies in the Pacific: red cell antigen, serum protein, and enzyme systems. In A.V.S. Hill and S.W. Serjeantson (eds) The colonization of the Pacific: a genetic trail, pp.60-119. Oxford: Clarendon Press.

Lilley, I.

1988 Prehistoric exchange across the Vitiaz Strait, Papua New Guinea. Current Anthropology 29(3):513-516.

Lynch, J.

1981 Melanesian diversity and Polynesian homogeneity: the other side of the coin. Oceanic Linguistics 20(2):95-129.

McArthur, N., I.W. Saunders and R.L. Tweedie

1976 Small population isolates: a micro-simulation study. Journal of the Polynesian Society 85(3):307-326.

Pawley, A.

1981 Melanesian diversity and Polynesian homogeneity: a unified explanation for language. In J. Hollyman and A. Pawley (eds) Studies in Pacific languages and cultures in Honour of Bruce Biggs, pp.269-309. Auckland: Linguistic Society of New Zealand.

Pawley, A. and R. Green

1973 Dating the dispersal of the Oceanic languages. Oceanic Linguistics 12:167.

Poulsen, J.

1987 Early Tongan prehistory, 2 vols. Terra Australis No.12. Canberra: Department of Prehistory, Research School of Pacific Studies, The Australian National University.

Roberts, R.G., R. Jones and M.A. Smith

1990 Thermoluminescence dating of a 50,000 year old human occupation site in northern Australia. Nature 345:153-156.

Ross, $\mathrm{M}$.

1988 Proto-Oceanic and the Austronesian languages of Western Melanesia. Pacific Linguistics Series C No. 98. Canberra: Department of Linguistics, Research School of Pacific Studies, The Australian National University.

1989 Early Oceanic linguistic prehistory. Journal of Pacific History 24:135149.

Serjeantson, S.W. and A.V.S. Hill 
1989 The colonization of the Pacific: the genetic evidence. In A.V.S. Hill and S.W. Serjeantson (eds) The colonization of the Pacific: a genetic trail, pp.286-294. Oxford: Clarendon Press.

Shutler, R. and J.C. Marck

1975 On the dispersal of the Austronesian horticulturalists. Archaeology and Physical Anthropology in Oceania 10:81-113.

Specht, J., I. Lilley and J. Normu

1981 Radiocarbon dates from West New Britain, Papua New Guinea. Australian Archaeology 12:13-15.

Spriggs, $M$.

1984 The Lapita cultural complex: origins, distribution, contemporaries and successors. Journal of Pacific History 19(3-4):202-223.

1989a The dating of the Island Southeast Asian Neolithic: an attempt at chronometric hygiene and linguistic correlation. Antiquity 63:587-613.

1990a Dating Lapita: another view. In M. Spriggs (ed.) Lapita design, form and composition: Proceedings of the Lapita design workshop, Canberra, December 1988, pp.6-27. Occasional Papers in Prehistory No. 19. Canberra: Department of Prehistory, Research School of Pacific Studies, The Australian National University.

Spriggs, M. (ed.)

1989b The Solomon Islands as bridge and barrier in the settlement of the Pacific. In W.S. Ayres (ed.) Southeast Asia and Pacific archaeology. Pullman: Washington State University Press.

1990b Lapita design, form and composition: Proceedings of the Lapita design workshop, Canberra, December 1988. Occasional Papers in Prehistory No. 19, Canberra: Department of Prehistory, Research School of Pacific Studies, The Australian National University.

1991 a Nissan: the island in the middle. In J. Allen and C. Gosden (eds) Report of the Lapita homeland project, pp.222-243. Occasional Papers in Prehistory No. 20. Canberra: Department of Prehistory, Research School of Pacific Studies, The Australian National University.

1991b Lapita origins, distribution, contemporaries and successors revisited. Bulletin of the Indo-Pacific Prehistory Association 11:306-312.

1992 Archaeological and linguistic prehistory in the North Solomons. In T. Dutton, M. Ross and D. Tryon (eds) The language game: Papers in memory of Donald C. Laycock. Pacific Linguistics Series C No. 110, pp.417-426. Canberra: Department of Linguistics, Research School of Pacific Studies, The Australian National University. 
1993 Island Melanesia, the last 10,000 years. In M. Spriggs et al. (eds) $A$ community of cultures, pp.187-205. Occasional Papers in Prehistory No. 21. Canberra: Department of Prehistory, Research School of Pacific Studies, The Australian National University.

Swadling, P., N. Araho and B. Ivuyo

1991 Settlements associated with the inland Sepik-Ramu sea. Bulletin of the Indo-Pacific Prehistory Association 11:92-112.

Swadling, P., B.H. Schäublin, P. Gorecki and F. Tiesler

1988 The Sepik-Ramu: an introduction. Port Moresby: National Museum.

Terrell, J.

1986 Prehistory in the Pacific Islands. Cambridge: Cambridge University Press. Torrence, R., J. Specht and R. Fullagar

1990 Pompeiis in the Pacific. Australian Natural History 23(6):456-463.

White, J.P., J. Allen and J. Specht

1988 Peopling the Pacific: the Lapita homeland project. Australian Natural History 22(9):410-416.

White, J.P. and J.F. O'Connell

1982 A prehistory of Australia, New Guinea and Sahul. Sydney: Academic Press.

Wickler, S. and M. Spriggs

1988 Pleistocene human occupation of the Solomon Islands, Melanesia. Antiquity 62:703-706.

Yen, D.E.

1982 The history of cultivated plants. In R.J. May and H. Nelson (eds) Melanesia: beyond diversity, Vol. 1, pp.281-295. Canberra: Research School of Pacific Studies, The Australian National University.

1985 Wild plants and domestication in Pacific Islands. In V.N. Misra and P.S. Bellwood (eds) Recent advances in Indo-Pacific prehistory, pp.315-326. Delhi: Oxford University Press and IBH.

1990 Environment, agriculture and the colonisation of the Pacific. In D.E. Yen and J.M.J. Mummery (eds) Pacific production systems, pp.258-277. Occasional Papers in Prehistory No. 18. Canberra: Department of Prehistory, Research School of Pacific Studies, The Australian National University. 


\section{Notes}

1 The evidence for this is the finding of two tanged obsidian blades at Mangum Village, East Sepik Province which have been sourced to Talasea (Swadling et al. 1988:20). In the Talasea area this blade industry is only found in pre-Lapita contexts (Torrence, Specht and Fullagar 1990). Another tanged obsidian artefact, presumably of similar age and source, was found between the Sepik and mountains south of Wewak, East Sepik Province (Swadling et al. 1988:19-20).

2 The derivation of Polynesian art from Lapita is discussed by Green (1979).

3 Some previous examinations of the prehistory of settlement in the Pacific and the cultural and linguistic diversity of the area have had recourse to geographic and particularly biogeographic principles (see for instance Pawley 1981 and Terrell 1986). Pawley's paper makes useful suggestions of processes which may have led to linguistic diversification in Pacific Island groups. His broader attempt at a "unified" explanation for Polynesian homogeneity and Melanesian diversity in language relies too much on a postulated much greater time depth for Lapita and Austronesian settlement in Melanesia (Pawley 1981:273-275) which is not sustainable on current archaeological evidence. His hypothesis has also been challenged on linguistic grounds (Lynch 1981). Terrell (1986) uses biogeographical principles which seem to me to be far too general in comparison with the detailed processes of specifically human migration discussed in Anthony's (1990) paper. 